\title{
PEMBUATAN BERAS ANALOG BERBAHAN DASAR TEPUNG SUKUN TERMODIFIKASI HEAT MOISTURE TREATMENT
}

\author{
Herry Santosa, Noer Abyor Handayani*, Ahmad Dzulfikar Fauzi, Anwar Trisanto \\ Departemen Teknik Kimia, Fakultas Teknik, Universitas Diponegoro \\ Jl. Prof. Soedarto, SH, Kampus Undip Tembalang, Semarang, Indonesia 50275 \\ Email: nora@undip.ac.id
}

\begin{abstract}
Abstrak
Beras merupakan sumber karbohidrat utama bagi masyarakat Indonesia.. Seiring dengan bertambahnya penduduk maka kebutuhan beras juga akan meningkat. Jika pemenuhan akan kebutuhan beras tersebut tidak dapat dipenuhi maka dikuatirkan akan menjadi ancaman terhadap ketahanan pangan nasional. Pemerintah berupaya mencegah permasalahan tersebut dengan cara menggerakkan upaya diversifikasi pangan. Salah satunya adalah rekayasa produk berupa beras analog.Tujuan utama dari penelitian ini adalah mengubah buah sukun menjadi beras analog dengan menerapkan proses modifikasi tepung secara HMT (Heat Moisture Treatment). Penelitian dilakukan melalui 3 tahap, yaitu (1) tahap penetuan variabel paling berpengaruh proses HMT, (2)tahap optimasi variabel paling berpengaruh, dan (3) tahap pembuatan beras analog. Variabel operasi paling berpengaruh dalam modifikasi HMT adalah suhu. Untuk memenuhi kriteria karakterisitk swelling power dan solubillity beras mentik, sebaiknya modifikasi dilakukan pada suhu $100^{\circ} \mathrm{C}$, waktu 1 jam dan kadar air 30\% w/w. Tepung sukun dapat dicetak menyerupai beras menggunakan ekstruder.
\end{abstract}

Kata kunci: beras analog, buah sukun, heat moisture treatment

\section{PENDAHULUAN}

Beras merupakan sumber karbohidrat utama dalam menu makan masyarakat Indonesia. Menurut data Badan Ketahanan Pangan Nasional (2015), kebutuhan beras pada tahun 2013 hingga 2015 sebesar 23,7 juta, 24,3 juta dan 28,5 juta ton beras. Tetapi dalam pemenuhannya, pada tahun tersebut Indonesia melakukan impor sebesar 472 ribu, 844 ribu dan 225 ribu ton beras (Badan Pusat Statistik, 2015). Jumlah penduduk Indonesia selama 25 tahun mendatang akan terus meningkat, yaitu dari 238,5 juta pada tahun 2010 menjadi 305,6 juta pada tahun 2035. Pemerintah telah berupaya untuk mencegah permasalahan ketahanan pangan nasional tersebut dengan cara menggerakkan upaya diversifikasi pangan. Rekayasa produk tersebut adalah teknologi beras tiruan atau beras analog. Beras analog merupakan beras tiruan yang berbentuk seperti beras yang dapat dibuat dari tepung non beras, seperti buah sukun (Noviasari, 2013).

Buah sukun (Artocarpus altilis) merupakan komoditas sumber karbohidrat potensial (Widowati, 2009). Sukun merupakan salah satu tanaman penghasil buah utama dari keluarga Moraceae Asal usul tanaman ini berasal dari daerah New Guinea, Pasifik yang kemudian berkembang ke
Malaysia hingga Indonesia. Buah sukun yang telah dijadikan tepung mempunyai kandungan mineral dan vitamin yang lebih tinggi dan lebih lengkap dibandingkan tepung beras (Suyanti dkk., 2003), dengan jumlah yang tidak melebihi ambang batas sesuai Peraturan Menteri Kesehatan No. 75 tahun 2013 sehingga aman jika dikonsumsi dengan jumlah dan frekuensi yang sama seperti nasi dari beras padi. Keunggulan nutrisi tepung sukun dan tepung beras ditampilkan pada Tabel 1. Penggunaan tepung sukun sebagai bahan baku pembuatan beras analog memiliki keterbatasan sifat fungsional pangan sehingga perlu dilakukan modifikasi.

Proses modifikasi dimaksudkan agar sifat fungsional pangan tepung mendekati atau menyamai karakteristik fungsional pangan beras. Modifikasi tepung sukun dapat dilakukan dengan metode Heat Moisture Treatment (HMT) dengan menggunakan kombinasi kadar air dan pemanasan diatas suhu gelatinisasi. Perlakuan HMT didefinisikan sebagai modifikasi pati secara fisika yang dilakukan pada granula pati dengan kadar air kurang dari 35\% (kondisi lembab) selama 15 menit sampai dengan 16 jam, dan pada suhu $80^{\circ} \mathrm{C}$ sampai dengan $120^{\circ} \mathrm{C}$ yang tidak menyebabkan pati mengalami proses gelatinisasi (Pangesti, 
2014). Salah satu kelebihan modifikasi pati dengan metode HMT adalah tidak melibatkan reaksi kimia dengan menggunakan reagen tertentu, sehingga tidak akan meninggalkan residu pada hasil pati termodifikasi.

Tabel 1. Perbandingkan Nutrisi

\begin{tabular}{|c|c|c|c|}
\hline No & Parameter & $\begin{array}{l}\text { Tepung } \\
\text { Sukun }\end{array}$ & $\begin{array}{l}\text { Tepung } \\
\text { Beras }\end{array}$ \\
\hline 1 & Kalori & $295 \mathrm{kcal}$ & $374 \mathrm{kcal}$ \\
\hline 2 & $\begin{array}{l}\text { Karbohidrat } \\
\text { total }\end{array}$ & $76 \mathrm{~g}$ & $80 \mathrm{~g}$ \\
\hline 3 & lemak total & $0,66 \mathrm{~g}$ & $0,66 \mathrm{~g}$ \\
\hline 4 & Protein & $2,33 \mathrm{~g}$ & $7,13 \mathrm{~g}$ \\
\hline 5 & $\begin{array}{l}\text { Serat } \\
\text { Pangan }\end{array}$ & $8,3 \mathrm{~g}$ & $1,3 \mathrm{~g}$ \\
\hline 6 & Kolestrol & $0 \mathrm{~g}$ & $0 \mathrm{~g}$ \\
\hline 7 & Folates & $39,2 \mu \mathrm{g}$ & $8,1 \mu \mathrm{g}$ \\
\hline 8 & Niacin & $2,520 \mathrm{mg}$ & $1,6 \mathrm{mg}$ \\
\hline 9 & Pyridoxine & $0,280 \mathrm{mg}$ & $0 \mathrm{mg}$ \\
\hline 10 & Riboflavin & $0,084 \mathrm{mg}$ & $0,051 \mathrm{mg}$ \\
\hline 11 & Thiamin & $0,2810 \mathrm{mg}$ & $0,072 \mathrm{mg}$ \\
\hline 12 & Vitamin A & $0 \mathrm{IU}$ & $0 \mathrm{IU}$ \\
\hline 13 & Vitamin C & $75,4 \mathrm{mg}$ & $0 \mathrm{mg}$ \\
\hline 14 & Vitamin E & $0,270 \mathrm{mg}$ & $0 \mathrm{mg}$ \\
\hline 15 & Vitamin $\mathrm{K}$ & $1,35 \mu \mathrm{g}$ & $0 \mu \mathrm{g}$ \\
\hline 16 & Potassium & $1,21 \mathrm{~g}$ & $0 \mathrm{mg}$ \\
\hline 17 & Sodium & $5 \mathrm{mg}$ & $0 \mathrm{mg}$ \\
\hline 18 & Calcium & $41 \mathrm{mg}$ & $28 \mathrm{mg}$ \\
\hline 19 & Zat besi & $1,3 \mathrm{mg}$ & $0,80 \mathrm{mg}$ \\
\hline 20 & Magnesium & $57 \mathrm{mg}$ & $25 \mathrm{mg}$ \\
\hline 21 & Phosporus & $67 \mathrm{mg}$ & $115 \mathrm{mg}$ \\
\hline 22 & Zinc & $0,37 \mathrm{mg}$ & $1,09 \mathrm{mg}$ \\
\hline 23 & Kadar Air & $10,6 \mathrm{~g}$ & $9,2 \mathrm{~g}$ \\
\hline
\end{tabular}

(USDA Food Nutrition Database,2016)

Keberhasilan proses modifikasi metode HMT ditentukan oleh faktor suhu operasi , dimana semakin tinggi suhu dan semakin lama waktu HMT, maka semakin kecil solubility pada pati ubi jalar (Sunyoto, 2016). Menurut Zavareze dan Dias (2011), penurunan solubility seiring dengan perlakuan HMT dikarenakan adanya penyusunan kembali granula pati yang menyebabkan menguatnya ikatan intramolekular, terbentuknya gugus amilopektin yang lebih teratur dan formasi amilosa-lipid yang kompleks. Faktor selanjutnya yang berpengaruh adalahwaktu operasi, menurut Pranoto, dkk (2014) menyatakan bahwa semakin lamanya waktu pemanasan, maka semakin banyak terjadi peningkatan interaksi ikatan molekular pada pati yang disebabkan karena molekul pati kehilangan formasi double helix sehingga swelling volume menjadi terbatas. Selain itu semakin lama waktu operasi maka granula pati menjadi lebih kuat karena terjadi penyusunan kembali antara amilosa dan amilopektin (Sunyoto, 2016). Penambahan kadar air (\%w) merupakan faktor lain yang menyebabkan reformasi struktur amilosa dan amilopektin, sehingga granula pati lebih mudah menyerap air.

Penelitian ini dimaksudkan untuk karakterisasi bahan baku (tepung sukun). Penentuan variabel paling berpengaruh, dan optimasi kondisi operasi proses modifikasi HMT juga dipelajari dalam penelitian ini.

\section{METODE PENELITIAN \\ 2.1. Bahan}

Bahan baku untuk penelitian ini adalah buah sukun, air suling, natrium bisulfit. Buah sukun didapat dari pertanian di daerah kalasan, Sleman Yogyakarta. Air suling diperoleh dari Unit Reverse Osmosis (RO) yang tersedia di Departemen Teknik Kimia Universitas Diponegoro Semarang. Natrium Bisulfit didapat dari Toko Multi Kima Raya

\subsection{Modifikasi Menggunakan Metode HMT}

Untuk mencapai sasaran dalam penelitian ini, penelitian akan dilakukan dalam 4 tahapan sebagai berikut :

1. Tahap pembuatan tepung sukun

2. Tahap karakterisasi tepung sukun

3. Tahap modifikasi tepung sukun secara Heat moisture treatment

\section{Tahap Penepungan}

Tahap ini bertujuan untuk mengubah bahan mentah berupa buah sukun menjadi tepung sukun 80-100 mesh. Buah sukun yang telah dikupas kulitnya dipotong-potong dengan ketebalan kurang lebih $1 \mathrm{~cm}$. proswes pencucian dengan air dan perendaman dengan Na-metabisulfit $0,2 \%$ selama 15 menit dilakukan untuk mendapatkan daging buah sukun yang bersih. Daging buah suku yang telah ditiriskan kemudian dikeringkan dengan 
menggunakan oven pada suhu $60^{\circ} \mathrm{C}$ selama 32 jam. Hasil pengeringan kemudian di giling dan diayak untuk mendapatkan ukuran tepung sebesar 80 mesh.

Tahap Modifikasi Tepung Sukun Secara Heat Moisture Treatment

- Penentuan Variabel Paling Berpengaruh

- Optimasi Variabel Paling Berpengaruh

\section{Tahap Penentuan Variabel Paling Berpengaruh}

Tahap ini bertujuan untuk menentukan variabel yang paling berpengaruh terhadap keberhasilan proses modifikasi tepung sukun (Gambar 1).

\section{Tahap Optimasi Variabel Paling berpengaruh}

Tahap ini bertujuan untuk mengkaji dan menentukan kondisi relatif baik dari variabel operasi yang paling berpengaruh berdasarkan karakterisitik tepung sukun yang sesuai atau mendekati karakteristik beras Mentik Wangi (Gambar 2).

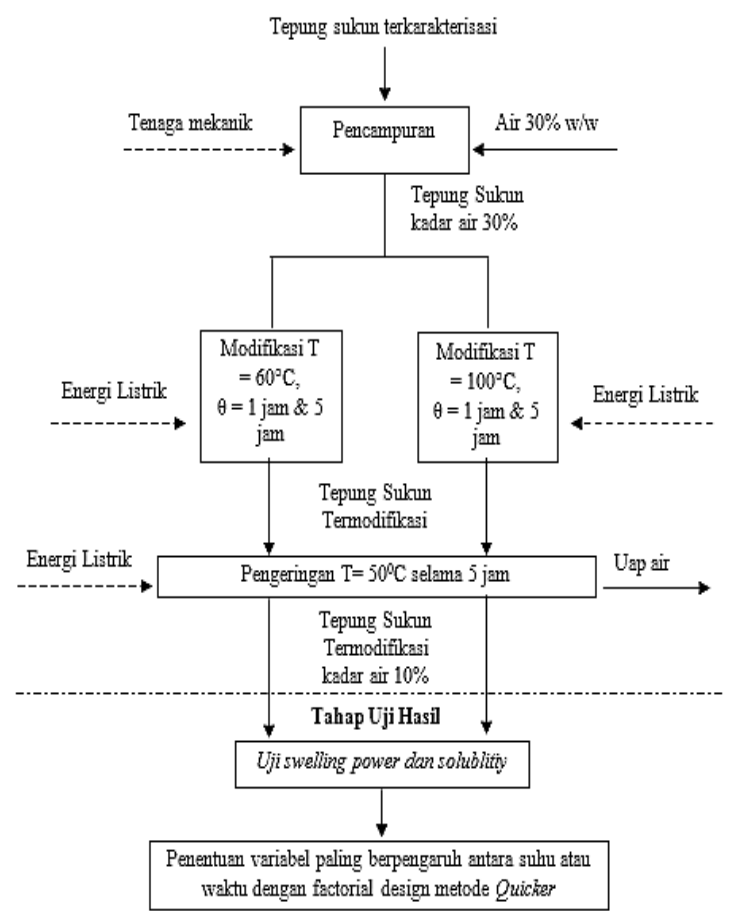

Gambar 1. Diagram alir tahap penentuan variabel yang paling berpengaruh

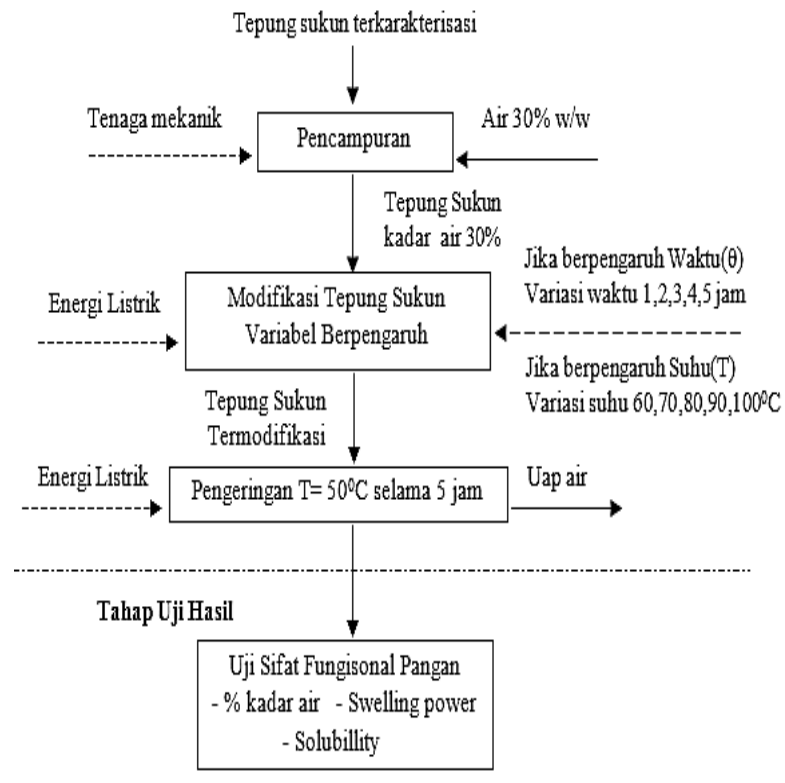

Gambar 2. Diagram alir penentuan kondisi relatif baik variabel yang paling berpengaruh

\section{Tahap Pembuatan Beras Analog}

Tahap ini bertujuan untuk membuat beras analog dengan bahan baku tepung sukun termodifikasi. Tepung sukun termodifikasi dicampur dengan air 50\% (w/w) dan GMS 2\% $(\mathrm{w} / \mathrm{w})$. adonan tersebut dimasukkan kedalam ekstruder untuk mendapatkan potongan adonan dengan ukuran panjang $7 \mathrm{~mm}$ dan diameter $3 \mathrm{~mm}$. Proses pengeringan potongan adonan dilakukan menggunakan oven pada suhu $60^{\circ} \mathrm{C}$ selama 5 jam untuk mendapatkan beras analog dengan kadar air $10 \%$.

\section{HASIL DAN PEMBAHASAN} Modifikasi Heat Moisture Treatment (HMT)

Berdasarkan data karakteristik tepung sukun dan beras mentik pada Tabel 2, dapat disimpulkan bahwa karakteristik fungsional pangan tepung sukun tidak sesuai dengan karakteristik beras mentik wangi. Kadar amilosa tepung sukun lebih tinggi yaitu $32,49 \%$ dibandingkan beras mentik wangi sebesar $28,88 \%$. Nilai swelling power tepung sukun juga lebih tinggi yaitu sebesar 7,04 dibandingkan dengan beras mentik wangi sebesar 5,04. Sedangkan nilai solubility tepung sukun lebih rendah yakni 5,73\% dibandingkan tepung mentik wangi sebesar 26,31\% (Santosa dan Nugraha, 2017). Oleh karena itu, perlu dilakukan upaya modifikasi agar karakteristik tepung sukun sesuai atau mendekati karakteristik tepung mentik wangi. 
Tabel 2 Hasil karakterisasi Sifat Fungsional Pangan Tepung Sukun dan Beras Mentik Wangi

\begin{tabular}{lcc}
\hline $\begin{array}{l}\text { Parameter } \\
\text { Fungsional } \\
\text { Pangan }\end{array}$ & $\begin{array}{l}\text { Tepung } \\
\text { Sukun }\end{array}$ & $\begin{array}{l}\text { Beras } \\
\text { Mentik } \\
\text { Wangi }\end{array}$ \\
\hline $\begin{array}{l}\text { Kadar Amilosa (\%) } \\
\text { Swelling Power } \\
\text { (g/g) }\end{array}$ & 32,49 & 28,88 \\
Solubility (\%) & 7,40 & 5,03 \\
\hline
\end{tabular}

(Sumber : Santosa, H. dan Nugroho, A., 2017)

Kadar amilosa mempengaruhi tekstur bahan pangan. Semakin tinggi kadar amilosa akan membuat nasi yang dihasilkan semakin keras (pera). Sebaliknya semakin rendah amilosa maka akan semakin lengket (Winarno, 1981). Swelling power adalah kemampuan pati untuk mengembang jika dipanaskan pada suhu dan waktu tertentu (Balagopalan et al., 1988 dalam Baah, 2009). Semakin besar nilai swelling power maka kemampuanpengembangan dan volume semakin besar. Bahan pangan dengan volume besar akan memberikan efek lebih kenyang. Tetapi volume besar dengan jumlah massa yang sedikit akan memberikan energi dan asupan gizi yang sedikit. Sedangkan solubillity didefinisikan sebagai kemampuan tepung untuk larut di dalam air. Semakin tinggi kelarutannya, maka semakin tinggi pula kemampuan tepung larut di dalam air (Tan et $a l ., 2010)$. Semakin mudah larut di dalam air, maka akan semakin mudah untuk dicerna. Hal tersebut membuat lambung akan lebih cepat kosong dan menyebabkan rasa lapar lebih cepat. Sehingga konsumsi terhadap bahan pangan tersebut lebih tinggi.

\section{Data Karakteristik Fungsional Pangan Hasil Modifikasi HMT}

Modifikasi HMT dilakukan dengan tujuan mengubah karakteristik fungsional pangan tepung sukun sesuai atau mendekati karakteristik beras mentik wangi. Data swelling power dan solubillity hasil modifikasi disajikan pada Tabel 3 yang selanjutnya digunakan untuk menghitung dan menentukan variabel operasi yang paling berpengaruh.
Tabel 3. Data Swelling Power Tepung

Sukun Termodifikasi HMT

\begin{tabular}{cccc}
\hline \multicolumn{2}{c}{ Variabel } & \multicolumn{2}{c}{$\begin{array}{c}\text { Respon Fungsional } \\
\text { Pangan }\end{array}$} \\
\hline $\begin{array}{c}\text { Suhu } \\
\left({ }^{\circ} \text { C) }\right.\end{array}$ & $\begin{array}{c}\text { Waktu } \\
(\text { jam })\end{array}$ & $\begin{array}{c}\text { Swelling } \\
\text { Power } \\
(\mathbf{g r} / \mathbf{g r})\end{array}$ & $\begin{array}{c}\text { Solubillity } \\
(\%)\end{array}$ \\
\hline 60 & 1 & 7,15 & 7,89 \\
60 & 5 & 6,81 & 7,47 \\
100 & 1 & 5,84 & 21,05 \\
100 & 5 & 5,55 & 12,61 \\
\hline
\end{tabular}

Perhitungan dan Penentuan Variabel Operasi paling Berpengaruh

Data karakteristik selanjutnya digunakan untuk menghitung nilai efek variabel paling berpengaruh. Variabel paling berpengaruh ditentukan dengan cara rancangan faktorial menggunakan metode quicker pada Tabel 4 dan 5 .

Berdasarkan hasil karakterisasi, upaya modifikasi bertujuan untuk menurunkan nilai swelling power agar sesuai atau mendekati karakteristik beras mentik wangi. Oleh karena itu, penentuan variabel paling berpengaruh didasarkan pada nilai efek yang memberikan efek negatif atau penurunan terbesar. Sedangkan pada solubility, upaya modifikasi untuk menaikkan nilai solubility agar sesuai atau mendekati karakteristik beras mentik wangi. Oleh karena itu, penentuan variabel paling berpengaruh didasarkan pada nilai efek yang memberikan efek positif atau kenaikan terbesar. Berdasarkan Tabel 4 dan 5, maka dapat disimpulkan variabel operasi paling berpengaruh adalah suhu karena memiliki nilai efek negatif terbesar pada swelling power dan nilai positif terbesar pada solubility.

\section{Optimasi Suhu sebagai Variabel Paling Berpengaruh}

Tahap ini bertujuan untuk mengkaji dan menentukan kondisi relatif baik dari variabel operasi yang paling berpengaruh berdasarkan karakterisitik tepung sukun yang sesuai atau mendekati karakteristik beras mentik wangi. Pada uji sebelumnya variabel berpengaruh yang didapat berupa suhu sehingga perlu dioptimasi, sedangkan waktu dijadikan variabel tetap diambil nilai selama 1 jam. Dan kadar air tetap pada $30 \%$. 
Tabel 4 Perhitungan Nilai Efek Variabel Operasi berdasarkan Nilai Swelling Power

\begin{tabular}{|c|c|c|c|c|c|c|}
\hline \multirow{2}{*}{ Percobaan } & \multicolumn{2}{|c|}{ Variabel } & \multirow{2}{*}{$\begin{array}{l}\text { Swelling } \\
\text { Power (g/g) }\end{array}$} & \multicolumn{2}{|c|}{ Efek Utama } & \multirow{2}{*}{$\begin{array}{c}\begin{array}{c}\text { Efek } \\
\text { Interaksi }\end{array} \\
\text { T } \boldsymbol{\theta} \\
\text { (suhu-waktu) }\end{array}$} \\
\hline & $\begin{array}{c}\text { Suhu } \\
\left({ }^{0} \mathrm{C}\right)\end{array}$ & $\begin{array}{c}\text { Waktu } \\
\text { (jam) }\end{array}$ & & $\begin{array}{c}\text { T } \\
\text { (suhu) }\end{array}$ & $\begin{array}{c}\theta \\
\text { (waktu) }\end{array}$ & \\
\hline 1 & 60 & 1 & 7.15 & -7.15 & -7.15 & +7.15 \\
\hline 2 & 60 & 5 & 6,81 & $-6,81$ & $+6,81$ & $-6,81$ \\
\hline 3 & 100 & 1 & 5,84 & $+5,84$ & $-5,84$ & $-5,85$ \\
\hline 4 & 100 & 5 & 5,55 & $+5,55$ & $+5,55$ & $+5,55$ \\
\hline \multicolumn{4}{|c|}{ Perhitungan Efek } & $-1,285$ & $-0,315$ & 0,02 \\
\hline
\end{tabular}

Tabel 5 Perhitungan Nilai Efek Variabel Operasi berdasarkan Nilai Solubility

\begin{tabular}{|c|c|c|c|c|c|c|}
\hline \multirow[b]{2}{*}{ Percobaan } & \multicolumn{2}{|c|}{ Variabel } & \multirow[b]{2}{*}{$\begin{array}{c}\text { Swelling Power } \\
\text { (g/g) }\end{array}$} & \multicolumn{2}{|c|}{ Efek Utama } & \multirow{2}{*}{$\begin{array}{c}\text { Efek Interaksi } \\
\text { T } \theta \\
\text { (suhu-waktu) }\end{array}$} \\
\hline & $\begin{array}{l}\text { Suhu } \\
\left({ }^{0} \mathrm{C}\right)\end{array}$ & $\begin{array}{c}\text { Waktu } \\
\text { (jam) }\end{array}$ & & $\begin{array}{c}\mathbf{T} \\
\text { (suhu) }\end{array}$ & $\begin{array}{c}\theta \\
\text { (waktu) }\end{array}$ & \\
\hline 1 & 60 & 1 & 7,89 & $-7,89$ & $-7,89$ & $+7,89$ \\
\hline 2 & 60 & 5 & 7,47 & $-7,47$ & $+7,47$ & $-7,47$ \\
\hline 3 & 100 & 1 & 21,05 & $+21,05$ & $-21,05$ & $-21,05$ \\
\hline 4 & 100 & 5 & 12,61 & $+12,61$ & $+12,61$ & $+12,61$ \\
\hline \multicolumn{4}{|c|}{ Perhitungan Efek } & $+9,15$ & $-4,43$ & $-4,01$ \\
\hline
\end{tabular}

Tabel 6. Hasil optimasi variabel berpengaruh

\begin{tabular}{ccc}
\hline $\begin{array}{c}\text { Variabel } \\
\left(\mathbf{s u h u},{ }^{\circ} \mathbf{C}\right)\end{array}$ & $\begin{array}{c}\text { Swelling power } \\
(\mathbf{g r} / \mathbf{g r})\end{array}$ & $\begin{array}{c}\text { Solubillity } \\
(\mathbf{\%})\end{array}$ \\
\hline 60 & 7,15 & 7,89 \\
70 & 6,97 & 9,66 \\
80 & 6,42 & 12,84 \\
90 & 5,95 & 16,32 \\
100 & 5,84 & 21,05 \\
\hline
\end{tabular}

Berdasarkan data hasil optimasi pada Tabel 6, diketahui bahwa semakin tinggi suhu operasi maka nilai swelling power tepung sukun semakin menurun. Hal ini disebabkan karena perlakuan pemanasan menyebabkan terjadinya pengaturan kembali molekul pati yang mengakibatkan menurunnya kapasitas pengembangan granula pati (Hormdok dan Noomhorm, 2007). Wang, dkk. (2006) juga menyatakan bahwa semakin tinggi suhu pemanasan, maka semakin banyak terbentuk kristalin baru yang dapat meningkatkan stabilitas granula dan mengurangi kemampuan pembengkakan granula. Menurut Vieira dan Sarmento (2008) serta Adebowale (2005), suhu mempengaruhi perubahan kristalin dan memberikan perubahan pada kapasitas pembengkakan pati. Seiring meningkatnya suhu, maka semakin banyak terbentuk amilosa-lipid yang kompleks sehingga menurunkan kapasitas pembengkakan pati (Olayinka, dkk., 2008).

Berdasarkan Tabel 6, semakin tinggi suhu operasi justru membuat nilai sollubility semakin meningkat. Hal tersebut berkebalikan dengan fenomena swelling power. Meskipun kapasitas pengembangan menurun sebagai akibat stabilitas granula pati meningkat dan terbentuknya kompleks amilosa-lipid (Olayinka, dkk., 2008), nilai sollubility tepung justru meningkat seiring dengan bertambahnya waktu. Hal tersebut disebabkan karena terjadinya starch damage pada saat penggilingan tepung sukun. Makin tinggi starch damage menyebabkan banyak daerah kristalin berubah menjadi daerah amorph sehingga menurunkan kekuatan asosiasi granula (Suksomboon et al., 2005). Hal tersebut menyebabkan jumlah amilosa yang di-leaching meningkat seiring kenaikan suhu (Santosa dkk., 2015). Semakin tinggi suhu, semakin banyak amilosa yang keluar dari granula pati menyebabkan semakin tinggi nilai kelarutan atau solubillity tepung sukun.

Perlakuan modifikasi bertujuan untuk membuat tepung sukun memiliki karakteristik swelling power dan solubiity yang menyerupai atau mengungguli tepung mentik wangi. Untuk parameter swelling power, tepung sukundiharapkan memiliki nilai yang lebih rendah dibanding tepung mentik wangi. Jika dilihat pada Tabel 6, semakin tinggi suhu 
menyebabkan semakin menurunnya nilai swelling power. Kecenderungan tersebut juga berlaku untuk suhu operasi di atas $100^{\circ} \mathrm{C}$. Tetapi suhu operasi tersebut dapat menyebabkan terjadinya pencoklatan dan merusak komponen gizi yang terkandung pada tepung sukun.

Sedangkan untuk sollubility, berdasarkan Tabel 6 semakin tinggi suhu operasi maka semakin meningkat nilai solubillity tepung sukun. Kecenderungan tersebut juga berlaku untuk suhu operasi di atas $100^{\circ} \mathrm{C}$. Tetapi dengan alasan yang sama dengan swelling power, suhu operasi tersebut dapat menyebabkan pencoklatan dan kerusakan kandungan gizi pada tepung sukun. Selain itu, untuk nilai solubillity diharapkan lebih rendah dibanding tepung mentik wangi agar tidak mudah larut selama proses pencernaan dan memberikan rasa kenyang yang lebih lama.

Penentuan kondisi relatif baik didasarkan pada nilai swelling power dan solubillity yang paling mendekati karakteristik tepung mentik wangi pada Tabel 2. Oleh karena itu, dapatdisimpulkan bahwakondisi relatif baik modifikasi Heat Moisture Treatment pada suhu operasi $100^{\circ} \mathrm{C}$.

\section{Pembuatan Beras Analog}

Pada tahap ini bahan baku yang digunakan adalah tepung sukun termodifikasi HMT dengan suhu operasi pada kondisi relatif baik $\left(100^{\circ} \mathrm{C}\right)$ yang kemudian dicetak menggunakan ekstruder agar menyerupai beras. Bahan baku tepung sukun yang digunakan berhasil dicetak menjadi beras analog. Namun beras tersebut memiliki beberapa kekurangan, yakni sifat beras yang dihasilkan lebih rapuh atau mudah hancur dan butiran beras mengalami pencoklatan serta menjadi pahit. Hal tersebut terjadi karena disebabkan oleh beberapa alasan sebagai berikut :

\section{a. Suhu pemasakan awal terlalu tinggi}

Pemasakan awal merupakan tahap awal untuk mempersiapkan bahan baku beras analog agar mudah dicetak menyerupai beras. Pemasakan awal melibatkan proses gelatinisasi yang terjadi pada pati bahan baku. Proses gelatinisasi merupakan proses masuknya air kedalam pati yang menyebabkan granula mengembang dan akhirnya pecah. Sedangkan suhu dimana terjadi gelatinisasi disebut dengan suhu gelatinisasi. Proses gelatinisasi menyebabkan perubahan viskositas larutan pati (Bastian, 2011). Untuk mendapatkan beras analog yang bagus, suhu gelatinisasi pati bahan baku harus diperhatikan. Suhu gelatinisasi pati berkisar antara $61-77.5^{\circ} \mathrm{C}$, selanjutnya dibutuhkan suhu pemasakan yang lebih tinggi untuk membentuk pasta (Rizki, 2016). Ketika mencapai suhu gelatinisasi, panas akan memutus ikatan antara amilosa dan amilopektin hingga amilosa keluar dari granula pati, kemudian air akan lebih banyak lagi masuk ke dalam granula pati. Proses ini menyebabkan granula membengkak dan pecah. Proses pembengkakan menyebabkan viskositas larutan menjadi tinggi. Viskositas akan menurun jika suhu terus dipertahankan kemudian akan naik lagi jika suhu diturunkan. Dalam kondisi suhu yang rendah, amilosa yang telah keluar dari granula akan mengeluarkan air (sineresis) hingga menyebabkan viskositas larutan kembali naik namun tidak setinggi pada saat gelatinisasi sempurna. Proses ini disebut dengan proses retrogadasi (Bastian,2011).

Pada proses pembuatan beras analog, beras mengalami pemasakan awal atau gelatinisasi. Kemudian dicetak menyerupai beras dan dikeringkan untuk menurunkan kadar airnya. Proses keluarnya air dari dalam sel menjadikan butiran beras berpori dan struktur beras menjadi terbuka. Struktur yang terbuka ini menyebabkan beras mampu menyerap air dalam jumlah yang besar dan beras cepat untuk terehidrasi (Rizki, 2016). Untuk menghasilkan beras analog yang bagus, suhu pemasakan awal bahan baku harus dilakukan pada range suhu diatas suhu gelatinisasinya. Hal ini bertujuan agar tepung mudah dibentuk menjadi beras analog. Namun apabila proses pemasakan awal dilakukan di bawah suhu gelatinisasinya, beras analog yang dihasilkan memiliki sifat yang keras dan sukar untuk dibentuk. Sedangkan jika proses pemasakan awal dilakukan pada suhu dan kadar air yang terlalu tinggi, maka akan menyebabkan beras yang dihasilkan lebih rapuh dan mudah rusak.

Pada saat pembuatan beras analog, metode yang digunakan dalam penelitian ini adalah metode pengukusan sebagai tahap pemasakan awal. Hal ini mengikuti desain alat yang digunakan. Bahan baku dikukus secara batch terlebih dahulu dan setelah itu di ekstruksi hingga berbentuk menyerupai beras. 
Proses ini memiliki kelebihan yaitu proses lebih cepat dan efisiensi biaya energi yang lebih baik. Namun proses ini memiliki kekurangan, yaitu pada saat pemasakan awal, tepung dipanaskan pada suhu jauh melebihi suhu gelatinisasinya dan menyebabkan kadar air yang tinggi pada bahan baku. Semula tujuan proses tersebut agar tepung tidak mendingin dengan cepat selama ekstruksi agar beras yang dihasilkan tidak keras. Akan tetapi pemanasan awal dengan cara pengukusan tersebut yang berada pada suhu $\pm 100^{\circ} \mathrm{C}$ menyebabkan beras yang dihasilkan lebih rapuh dan mudah hancur.

\section{b. Kadar amilosa yang tinggi}

Amilosa memiliki sifat yang sulit membentuk gel dalam air. Hal ini dapat dilihat pada pati yang memiliki kandungan amilosa yang tinggi seperti pada pati beras. Saat proses pemasakan pati dalam larutan air menyebabkan amilosa keluar dari granula pati kemudian larut dalam air. Apabila dalam keadaan dingin amilosa tersebut akan terretrogradasi hingga membentuk lapisan lapisan kerak atau lapisan film. Hal ini dapat diamati saat memasak nasi akan muncul lapisan - lapisan yang berbentuk film putih transparan pada dinding - dinding panci. Lapisan - lapisan tersebut merupakan amilosa yang telah larut dalam air dan kemudian terretrogradasi hingga membentuk lapisan film. Amilopektin memiliki sifat retrogradasi lebih kecil daripada amilosa karena amilopektin memiliki rantai bercabang yang cukup banyak. Sifat retrogradasi yang kecil pada amilopektin menyebabkan amilopektin dapat mempertahankan sifat gel yang terbentuk (Bastian, 2011). Dalam hal ini jika kadar amilosa yang dikandung terlalu tinggi akan menyebabkan tepung sulit dibentuk menjadi beras analog sehingga beras yang dihasilkan cenderung lebih rapuh sedangkan jika amilopektin yang dikandung terlalu tinggi akan menyebabkan beras analog terlalu lembek.

Pada penelitian ini kadar amilosa yang dikandung beras sebesar $28,88 \%$ sedangkan untuk tepung sukun sendiri sekitar 32,49\%. Kadar amilosa yang terlalu tinggi menyebabkan tepung sulit dibentuk menjadi beras analog dan beras dihasilkan cenderung rapuh. Selain itu kurangnya kadar amilopektin juga berpengaruh yaitu terbentuknya gel yang berguna sebagai perekat dalam pencetakan beras.

\section{c. Pencoklatan Non-Enzymatis}

Beras analog yang dihasilkan pada penelitian ini berwarna coklat dan cenderung berasa pahit. Menurut Nursten (2005), pencoklatan pada bahan pangan secara umum disebabkan oleh 2 hal, yakni pencoklatan enzimatis dan pencoklatan non-enzimatis. Pencoklatan enzimatik merupakan proses pencoklatan yang sering terjadi pada produk buah, umbi dan sayur -sayuran yang disebabkan karena terjadinya oksidasi terhadap kandungan senyawa fenolik di dalamnya. Sedangkan pencoklatan nonenzimatis bukan merupakan pencoklatan akibat aktivitas enzim melainkan karena proses pengolahan pada bahan pangan tersebut.

Beras analog yang dihasilkan pada penelitian mengalami pencoklatan pada saat proses pengukusan. Menurut Mizobutsi et al. (2010), senyawa enzim polifenol oksidase yang terkandung dalam buah sukun secara sempurna mengalami inaktivasi pada paparan suhu $60^{\circ} \mathrm{C}$. Nursten (2005) juga menyatakan bahwa pencoklatan bahan pangan sebagai akibat paparan suhu tinggi bukan disebabkan karena pencoklatan enzimatik, tetapi karena pencoklatan non-enzimatik. Sehingga dapat disimpulkan bahwa pencoklatan yang terjadi pada beras analog bukan karena aktivitas enzim melainkan pencoklatan non enzimatik sebagai akibat proses pengukusan.

Pencoklatan non enzimatik pada beras analog yang dihasilkan pada penelitian ini disebabkan karena terjadinya reaksi Maillard. Reaksi Maillard terjadi karena adanya reaksi antara gula pereduksi dengan dengan gugus amin bebas dari asam amino atau protein. Reaksi Maillard terjadi melalui beberapa tahap. Pada tahap awal, aldosa akan bereaksi bolak-balik dengan suatu gugus amino sehingga menghasilkan basa Schiff. Perubahan terjadi menurut reaksi amadori membentuk amino ketosa. Dehidrasi dari hasil reaksi amadori membentuk turunan - turunan fulfuraldehida. Proses dehidrasi selanjutnya menghasilkan metil alpha-dikarbonil yang diikuti penguraian menghasilkan reduktor reduktor dan alpha-dikarboksil seperti metaglioksal, asetol dan diasetil. Tahap akhir, aldehid aktif terpolimerisasi tanpa mengikutsertakan gugus amino (kondensasi 
aldol) membentuk senyawa berwarna coklat yang disebut melanoidin. Selain menghasilkan warna coklat, senyawa melanoidin memberikan cita rasa pahit yang khas pada bahan makanan (Arsa, M., 2016).

Reaksi Maillard berlangsung cepat pada suhu $100^{\circ} \mathrm{C}$ namun tidak terjadi pada suhu $150^{\circ}$ C. Kadar air $10-15 \%$ adalah kadar air terbaik untuk reaksi Maillard berlangsung, sedangkan pada kadar air yang terlalu rendah dan tinggi justru menyebabkan reaksi berjalan lambat (Arsa, M., 2016). Proses pengukusan terjadi pada suhu $\pm 100^{\circ} \mathrm{C}$ dan menyebabkan kadar air bahan meningkat. Hal tersebut memperbesar peluang terjadinya reaksi Maillard sehingga mengalami pencoklatan dan memiliki cita rasa pahit.

\section{KESIMPULAN}

Tepung sukun dapat dijadikan sebagai bahan baku beras analog melalui proses modifikasi HMT. Modifikasi lebih baik dilakukan pada kondisi operasi suhu $100^{\circ} \mathrm{C}$, waktu 1 jam dan kadar air 30\% w/w. Tepung sukun dapat dicetak menyerupai beras menggunakan ekstruder.Untuk mendapatkan butiran beras analog yang padat dan tidak mudah hancur, sebaiknya dilakukan penambahan bahan pangan tambahan yaitu Carboxymethyl Celluloce sebagai pengikat dengan batas maksimum $2 \% \mathrm{~b} / \mathrm{b}$ sesuai Permenkes nomor 22 tahun 2012. Untuk meminimalisir pencoklatan pada beras sukun, sebaiknya dilakukan pengukusan daging buah sukun sebelum dijadikan tepung sebagai bahan baku beras analog.

\section{DAFTAR PUSTAKA}

[AOAC] Association of Analytical Communities. 2007. Official Method of Analysis. Washington DC (US).

Adinugraha H.A., Kartikawati N.K., Setiadi D., dan Prastyono, 2014, Pengembangan Teknik Budidaya Sukun (Artocarpus altilis) untuk Ketahanan Pangan. Bogor: IPB Press.

Akanbi T.O., Nizamid S, and Adebowale A.A. 2009. Functional and Pasting Properties of a Tropical Breadfruit (Artocarpus altilis) starch from Ile Ife State Nigeeria. International Food Research Journal 16, pp. 151-157.

Aliawati, dan Gusnimar, 2003, Teknik Analisis Kadar Amilosa dalam Beras.
Buletin Teknik Pertanian, 8(2), pp. 8284.

Amin, dan Azizah, N, 2013, Pengaruh Suhu Fosforilasi terhadap Sifat Fisiokimia Pati Tapioka Termodifikasi, [Skripsi]. Fakultas Pertanian, Universitas Hasanudin, Makassar.

Badan Ketahanan Pangan Nasional, 2015, "Data Statistik Ketahanan Pangan Tahun 2014'. Jakarta : Kementerian Pertanian.

Badan Perencanaan Pembangunan Nasional, 2013, Proyeksi Penduduk Indonesia 2010 - 2035. Jakarta : Badan Pusat Statistik.

Bao, J.S., Cai, Y.Z., and Corke, H., 2001, Prediction of Rice Starch Quality Parameters by Near-Infrared Reflectance Spectroscopy., Journal Food Sci., 66, pp. 936-939.

Budiyati, C.S., Kumoro, A.C., Ratnawati, R., dan Retnowati, D.S., 2016, Modifikasi Pati Sukun (Artocarpus Altilis) dengan Teknik Oksidasi Menggunakan Hidrogen Peroksida Tanpa Katalis. Jurnal Teknik, 31(1), pp. 32-40

Gropper S.S., Smith J.L., and Groof J.L., 2009, Advanced Nutrition and Human Metabolism, Fifth Edition. Belmont : Wadsworth.

Kainuma, K., Odat, T., Cuzuki, S., 1967, Study of starch Phosphates Monoester. Journal Technol, Soc. Starch14, 24-28.

Kaur, L., Singh, J., and Singh, N., 2004, Effect of glycerol monostearat on the physic-chemical, thermal, rheological and noodle making properties of corn and potato starch. Journal Food Hydrocolloids, 19, pp. 839-849

Kementerian Kesehatan Republik Indonesia. 2013. Peraturan Menteri Kesehatan Republik Indonesia Nomor 75 Tahun 2013 tentang Angka Kecukupan Gizi yang Dianjurkan Bagi Bangsa Indonesia. Jakarta : Kementerian Kesehatan.

Leach, H. W., Mc Cowen, L.D., Schoch, T. J., 1959, Structure of The Starch Granules in Swelling and Sollubility Pattern of Various Starch. Cereal Chem, 36, pp. 534-544.

Mulyandari, S.H., 1992, Kajian Perbandingan Sifat-Sifat Pati Umbi-Umbian dan Pati Biji-Bijian [Skripsi]. Bogor : IPB. 
Murillo, C.E.C., Wang, Y.J., and Perez, L.A.B. 2008. Morphological, Physicochemical and Structural Characteristics of Oxidized Barley and Corn Starches. Starch/Stärke, 60, 634645.

Moorthy, S.N., 2004, Tropical sources of starch. Di dalam: Ann Charlotte Eliasson (ed). Starch in Food: Structure, Function, and Application. Baco Raton, Florida : CRC Press.

Noviasari, S., Kusnandar, F., Budijanto, S., 2013, Pengembangan Beras Anaog dengan Memanfaatkan Jagung Putih. Jurnal Teknologi dan Industri Pangan, 24(2)

Pomeranz, Y. 1985. Functional Properties of Food Components. New York : Academic Press, Inc.

Santosa, H., Handayani, N.A., Bastian, H.A., Kusuma, I.M., 2015, Modifikasi Tepung Ubi Jalar Ungu (Ipomoea batatas L. Poir) dengan Metode Heat Moisture Treatment (HMT) sebagai Bahan Baku Pembuatan Mie Instan. Jurnal Metana, 11(1), pp. 37-46.

Santosa, H., Nugroho, A., Fauzi, A.D., Trisanto, A., 2017, Modifikasi Tepung Sukun Menggunakan Teknik Heat Moisture Treatment, Sebagai Bahan Baku Pembuatan Beras Analog Dalam Rangka Menciptakan Ketahanan Pangan Nasional. Departemen Teknik Kimia, Fakultas Teknik, Universitas Diponegoro

Sindhuja, A., Sudha, M.L., and Rahim, A. 2005, Effect of incorporation of amaranth flour on the quality of cookies. Journal Eur Food Res Technol, 221, pp. 597-601

Singh, N., Sharma, S., and Singh, B., 2000, The effect of sodium bicarbonate and glycerol monostearate addition on the extrusion behaviour of maize grits. Journal of Food Engineering, 46, pp. 61-66.

Sistihapsari, F., dan Hakiim, A., 2011, Modifikasi Fisik-Kimia Tepung Sorgum Berdasarkan Karakteristik Sifat Fisiokimia Sebagai Substituen Tepung Sorgum [Artikel Penelitian]. Jurusan Teknik Kimia, Fakultas Teknik, Semarang.
Sunyoto, M., Amdoyo, R., Ramdani, H., Mochelle, C.T., 2016, Kajian Sifat Fungsional dan Amilografi Pati Ubi Jalar (Ipomea batatas L.) dengan Perlakuan Suhu dan Lama Waktu Heat Moisture Treatment sebagai Bahan Sediaan Pangan Darurat. Dipresentasikan saat Seminar Nasional Hasil Penelitan dan Pengabdian Masyarakat, Inovasi IPTEKS Perguruan Tinggi untuk Meningkatkan Kesejahteraan Masyarakat, Unmas, Bali Suyanti, S., Widowati dan Suismono, 2003, Teknologi Pengolahan tepung sukun dan Pemanfaatannya untuk Berbagai Produk Makanan Olahan. Jurnal Warta Penelitian Pengembangan Pertanian, 25(2), pp. 12-13.

Suriani, A.I., 2008. Mempelajari Pengaruh Pemanasan Dan Pendinginan Berulang Terhadap Karakteristik Sifat Fisik Dan Fungsional Pati Garut (Marantha Arundinacea) Termodifikasi [Skripsi]. Fakultas Teknologi Pertanian, IPB, Bogor.

Syamsir, E., Hariyadi, P., Fardiaz, D., Andarwulan, D., dan Kusnandar, F., 2012, Pengaruh Proses Heat Moisture Treatment Terhadap Karakteristik Fisiokimia Pati. Jurnal Teknologi dan Industri Pangan, 23(1)

Tester, R.F., and Morrison, W.R., 1990, Swelling and Gelatinization of Cereal Starches I, Effects of Amylopectin, Amylose, and Lipids. Cereal Chemistry, 67, pp. 551-557.

Tran, U.T., Okadome, M, Murata, S.H., and Ohtsubo, 2001, Comparison of Vietnamese and Japanese Rice Cultivars in Terms of Physicochemical Properties. Food Sci. Technol. Res. 7, pp. 323-330.

Widowati, S., dan Damardjati, D.S., 2001, Mengenal Sumber Daya Pangan Lokal dalam Rangka Ketahanan Pangan. Majalah Pangan No. 36/X/Jan/2001. BULOG, Jakarta.

Widowati, S. 2009. Prospek Sukun (Artocarpus communis) sebagai Pangan sumber Karbohidrat dalam Mendukung Diversifikasi Konsumsi Pangan. Maj. Pangan, 18(56), pp. 67-75.

Winarno, F.G., 2004. Kimia Pangan dan Gizi. Jakarta :Gramedia Pustaka Utama 